\title{
Host Plant Effects on Hybrids of Rhizobium leguminosarum Biovars viceae and trifolii
}

\author{
By C. L. WANG,$^{1} \dagger$ J. E. BERINGER ${ }^{2}$ AND P. R. HIRSCH ${ }^{1 *}$ \\ ${ }^{1}$ Soil Microbiology Department, Rothamsted Experimental Station, Harpenden, \\ Hertfordshire AL5 2JQ, UK \\ ${ }^{2}$ Unit of Molecular Genetics, University of Bristol, Woodland Road, Bristol BS8 IUG, UK
}

(Received 20 March 1986)

\begin{abstract}
The Rhizobium leguminosarum biovar viceae host-range plasmid pJB5JI was transferred to six $R$. leguminosarum biovar trifolii strains. Inheritance of pJB5JI enabled the $R$. leguminosarum biovar trifolii strains to nodulate both peas and clover species. Bacteria were isolated from nodules formed on peas (the 'correct' host for $R$. leguminosarum biovar viceae) and the hosts for $R$. leguminosarum biovar trifolii (white, red and subterranean clover). Isolates from peas and white clover appeared to have lost or changed the host-range plasmid conferring the ability to nodulate white clover or peas respectively. Isolates from subterranean and red clover could often nodulate all host plants. These results show that the host exerts some form of functional incompatibility when interacting with hybrid Rhizobium strains and that some hosts are more stringent than others.
\end{abstract}

\section{INTRODUCTION}

The Rhizobiaceae is a family of Gram-negative micro-organisms whose taxonomy is based primarily on their ability to interact with plants. Thus the genus Rhizobium is split into species and further subdivided into biovars on the basis of the legume plants on which particular isolates form $\mathrm{N}_{2}$-fixing nodules. For example, $R$. leguminosarum biovar trifolii nodulates clover (Trifolium spp.), biovar phaseoli nodulates Phaseolus spp. and biovar viceae nodulates pea (Pisum spp.), Vicia, Lens and Lathyrus. Until the recent re-classification of the Rhizobiaceae (Jordan, 1984), these biovars were defined as the three separate species $R$. trifolii, $R$. phaseoli and $R$. leguminosarum respectively. This classification is very useful in agriculture because the groupings determine whether a particular strain of Rhizobium will be suitable for inoculating a particular legume crop.

The value of plant nodulation responses as a taxonomic criterion was first seriously challenged by the observation by Higashi (1967) that the ability to nodulate clover could be transferred from $R$. leguminosarum biovar trifolii to $R$. leguminosarum biovar phaseoli. Later Johnston et al. (1978) reported that host range determination was plasmid-borne and could be transferred from $R$. leguminosarum biovar viceae to $R$. leguminosarum biovar trifolii and $R$. leguminosarum biovar phaseoli. This observation was expected because Johnston \& Beringer (1977) had previously shown that the chromosomes of these three biovars were apparently identical.

Beynon et al. (1980) reported that hybrids of $R$. leguminosarum biovar phaseoli carrying $R$. leguminosarum biovar viceae host-range genes could only nodulate peas (the 'correct' host for $R$. leguminosarum biovar viceae) if they had lost a plasmid carrying $R$. leguminosarum biovar phaseoli host-range genes, or if the genes were lost due to deletions in the plasmid. This work suggested that there was a functional incompatibility which prevented bacteria that carried, and presumably expressed, genes determining two different host ranges from nodulating particular hosts. Interestingly, when Phaseolus plants growing on agar were inoculated with the hybrids,

† Present address: Huazhong Agricultural University, Wuhan, Hubei, Peoples Republic of China. 
nodules were formed and contained bacteria which retained both host-range plasmids. The $R$. leguminosarum biovar viceae strain forms non- $\mathrm{N}_{2}$-fixing $\left(\mathrm{Fix}^{-}\right)$nodules on Phaseolus grown under these conditions and thus it was assumed that Phaseolus was a less discriminating host than the pea, which is not nodulated by $R$. leguminosarum biovar phaseoli.

Djordjevic et al. (1982), using the same $R$. leguminosarum biovar viceae host range plasmid (pJB 5JI) as we have used in this study, reported that the host influenced the stability of pJB5JI in $R$. leguminosarum biovar trifolii and that derivatives unable to nodulate peas had suffered a deletion of about $30 \mathrm{MDa}$ of pJB5JI DNA. Their work also indicated that the $\mathrm{Fix}^{+}$phenotype was less readily maintained than the broadened host range ability conferred by the presence of pJB5JI. Christensen \& Schubert (1983) have also studied the fate of pJB5JI in $R$. leguminosarum biovar trifolii strain T37, and have shown that it can interact with a host-range plasmid already present in this strain to produce strains with different plasmid profiles and symbiotic properties. They also reported that after isolation of $R$. leguminosarum biovar trifolii strains from clover nodules, over 30 isolates from 80 examined had lost kanamycin resistance conferred by pJB5JI.

It is clear from these studies that pJB5JI can confer an increased host range on $R$. leguminosarum biovar trifolii strains and that the plasmid, or most probably the expression of certain host range genes on it, is selected against when strains carrying two sets of host range genes nodulate clover plants. However, previous studies on the genetics and host plant responses to $R$. leguminosarum biovar trifolii strains carrying plasmids conferring two different host ranges have been restricted in the $R$. leguminosarum biovar trifolii strains used and clover species examined. While $R$. leguminosarum biovar trifolii strains usually nodulate most clover species, it is relatively unusual to find strains that are able to form $\mathrm{N}_{2}$-fixing nodules on all, indicating a clear genotype $\times$ genotype interaction between $R$. leguminosarum biovar trifolii and Trifolium species.

The purpose of this research was to determine whether the existing genotype interactions between $R$. leguminosarum biovar trifolii and clover species would affect the response of plants to inoculation with $R$. leguminosarum biovar trifolii strains containing $R$. leguminosarum biovar viceae host range genes. For host plants we used the pea (Pisum sativum cv. Dark Skinned Perfection), which is the 'correct' host for $R$. leguminosarum biovar viceae; and white clover (Trifolium repens, cv. S100), red clover ( $T$. pratense cv. S123) and subterranean clover $(T$. subterranean cv. Mount Barker), which are the 'correct' hosts for $R$. leguminosarum biovar trifolii. The different clover species were chosen because they differ in their ability to form $\mathrm{N}_{2}$-fixing nodules with the six $R$. leguminosarum biovar trifolii strains used in this study (Table 1). Subterranean clover also had the advantage for this study in that it is readily nodulated by $R$. leguminosarum biovar viceae strains, though the nodules never fix $\mathrm{N}_{2}$.

\section{METHODS}

Rhizobium strains and plasmids. The properties of the Rhizobium strains and plasmids and their plant nodulation features are listed in Table 1. Media and culture conditions were as described by Beringer (1974). Membrane crosses were as described by Beringer et al. (1978). Transconjugants were selected for the inheritance of kanamycin resistance (determined by transposon Tn 5 present on pJB5JI and then subcultured three times on minimal medium agar containing kanamycin before plants were inoculated.

Plant inoculation and nodule analysis. Seeds were surface-sterilized with $70 \%$ ethanol for $20 \mathrm{~s}$, followed by sodium hypochlorite $(8 \%, w / v$, available chlorine) for 5-10 min according to seed size and then washed 10 times in sterile water before they were transferred to $1 \%$ yeast mannitol (YM) agar (Vincent, 1970) for germination. The pea seeds were incubated for about $4 \mathrm{~d}$ in the dark at $28^{\circ} \mathrm{C}$. Sterilized clover seeds were kept at $4{ }^{\circ} \mathrm{C}$ overnight, then the plates were inverted and incubated at $28^{\circ} \mathrm{C}$. Pea plant growth conditions were as described by Beringer (1974) except that Perlite was used with Fahraeus solution (Fahraeus, 1957). Clover plants were grown on $1 \%$ agar Fahraeus slopes under the same conditions as for peas. Nodules were usually visible 1-2 weeks after infective bacteria had been added. Nodule nitrogenase activity was measured by $\mathrm{C}_{2} \mathrm{H}_{2}$ reduction as described by Johnston \& Beringer (1975). Between $10^{8}$ and $10^{9}$ rhizobia, washed from TY slopes in sterile water, were added to each plant.

Strain re-isolation. Full-size nodules were excised from the root and surface-sterilized by washing in $95 \%$ ethanol for 15-30 s before transfer to $6 \%$ hydrogen peroxide $\left(20\right.$ vols $\left.\mathrm{H}_{2} \mathrm{O}_{2}\right)$ for 2-5 min (according to nodule size). Nodules were rinsed in sterile distilled $\mathrm{H}_{2} \mathrm{O}$, then crushed and streaked on $\mathrm{YM}$ agar. Phenotypes of the re-isolated bacteria were checked by plating on suitable selective media and by analysis of plasmid profiles using agarose gel 
Table 1. Bacterial strains and plasmids

\begin{tabular}{|c|c|c|c|c|c|}
\hline \multirow[b]{2}{*}{ Strain } & & & & & \multirow[b]{2}{*}{ Reference/source } \\
\hline & Pea & $\begin{array}{l}\text { White } \\
\text { clover }\end{array}$ & $\begin{array}{l}\text { Red } \\
\text { clover }\end{array}$ & $\begin{array}{l}\text { Subterranean } \\
\text { clover }\end{array}$ & \\
\hline \multicolumn{6}{|c|}{$\begin{array}{l}\text { R. leguminosarum } \\
\text { biovar trifolii }\end{array}$} \\
\hline RCR5 & $\mathbf{N}^{-}$ & $\mathrm{F}^{+}$ & $\mathrm{F}^{+}$ & $\mathbf{F}^{-}$ & \multirow{6}{*}{$\begin{array}{l}\text { Field isolates } \\
\text { from the } \\
\text { Rothamsted } \\
\text { Culture } \\
\text { Collection }\end{array}$} \\
\hline RCR32 & $\mathrm{N}^{-}$ & $\mathrm{F}^{+}$ & $\mathrm{F}^{+}$ & $\mathrm{F}^{-}$ & \\
\hline RCR46 & $\mathrm{N}^{-}$ & $\mathrm{F}^{+}$ & $\mathrm{F}^{+}$ & $\mathrm{F}^{+}$ & \\
\hline RCR221 & $\mathrm{N}^{-}$ & $\mathrm{F}^{+}$ & $\mathrm{F}^{+}$ & $\mathrm{F}^{+}$ & \\
\hline RCR226 & $\mathrm{N}^{-}$ & $\mathrm{F}^{-}$ & $\mathrm{F}^{-}$ & $\mathrm{F}^{+}$ & \\
\hline RCR227 & $\mathrm{N}^{-}$ & $\mathrm{F}^{-}$ & $\mathrm{F}^{-}$ & $\mathrm{F}^{+}$ & \\
\hline \multicolumn{6}{|c|}{ R. leguminosarum } \\
\hline $\mathrm{T} 83 \mathrm{~K} 3$ & $\mathrm{~F}^{+}$ & $\mathrm{N}^{-}$ & $\mathrm{N}^{-}$ & $\mathrm{F}^{-}$ & Johnston et al. (1978) \\
\hline Strain & \multicolumn{4}{|c|}{ Relevant properties and plasmids } & Reference \\
\hline \multicolumn{6}{|c|}{$\begin{array}{l}\text { R. leguminosarum } \\
\text { biovar viceae }\end{array}$} \\
\hline $\begin{array}{l}\mathrm{J} 16015 \\
\mathrm{~T} 83 \mathrm{~K} 3\end{array}$ & \multicolumn{4}{|c|}{$\begin{array}{l}\mathrm{Phe}^{-} \mathrm{Trp}^{-} \mathrm{Str}^{\mathrm{R}} \mathrm{Rif}^{\mathrm{R}} \mathrm{Nod}^{-} \text {, produces small bacteriocin } \\
\text { JI6015 carrying pJB5JI, a transmissible symbiotic } \\
\text { plasmid marked with Tn5 conferring kanamycin resist- } \\
\text { ance }\end{array}$} & $\begin{array}{l}\text { Johnston et al. (1978) } \\
\text { Johnston et al. (1978) }\end{array}$ \\
\hline B151 & \multicolumn{4}{|c|}{$\begin{array}{l}\text { Non-nodulating derivative of strain } 128 \mathrm{C} 53 \text { cured of its } \\
\text { Sym plasmid }\end{array}$} & Brewin et al. (1982) \\
\hline \multirow{2}{*}{$\begin{array}{l}\text { E. coli } \\
\text { JI1830 }\end{array}$} & \multirow{2}{*}{\multicolumn{4}{|c|}{ Carries pJB4JI, a suicide vector for $\operatorname{Tn} 5$}} & \\
\hline & & & & & Beringer et al. (1978) \\
\hline
\end{tabular}

electrophoresis (Hirsch et al., 1980). Kanamycin-sensitive isolates which appeared to carry deleted derivatives of pJB5JI were investigated further by hybridizing blots from agarose gels with $\mathrm{Tn} 5$ and Klebsiella nif DNA probes as described by Hombrecher $e t$ al. (1981). Such deleted strains were also screened for bacteriocin production and sensitivity as described by Hirsch (1979).

\section{RESULTS}

\section{Transfer of plasmids between $R$. leguminosarum biovars viceae and trifolii}

Crosses were done using $R$. leguminosarum biovar viceae strain T83K3 as the donor of pJB5JI to the six wild-type strains of $R$. leguminosarum biovar trifolii. The transfer frequency (per recipient) of pJB5JI was $10^{-4}$ to RCR46 and $10^{-3}$ to the other five strains. Five single colonies were taken from each cross and, after purifying by subculturing three times on selective medium, the appropriate transconjugants were inoculated on both pea and clover plants. These plant tests showed that the pJB5JI derivatives of five of the six strains had inherited the ability to nodulate peas (Table 2), forming many small nodules; two of them formed $\mathrm{N}_{2}$-fixing (Fix ${ }^{+}$) nodules, while at the same time retaining their original symbiotic properties on clover plants. Compared to $R$. leguminosarum biovar trifolii controls, the rate of $\mathbf{N}_{2}$ fixation on clover plants was not significantly altered by the presence of pJB5JI in any of derivative strains (data not shown).

To test the stability of the kanamycin resistance determinant, all 30 transconjugants were subcultured three times on minimal medium agar without kanamycin. About 100 colonies for each were checked and none was found to have become kanamycin-sensitive. Thus the presence of $\mathrm{Tn} 5$ in pJB5JI was judged to be stable in laboratory cultures. When these strains were used to inoculate peas and clovers and were isolated from nodules, all isolates from peas were still kanamycin-resistant. However, kanamycin-resistance was frequently absent in transconjugants isolated from clover nodules (Table 2). 
Table 2. Symbiotic properties of $R$. leguminosarum biovar trifolii strains isolated from nodules

\begin{tabular}{|c|c|c|c|c|c|c|c|}
\hline \multirow[b]{2}{*}{ Strain } & \multirow[b]{2}{*}{$\begin{array}{l}\text { Initial } \\
\text { host* }\end{array}$} & \multirow[b]{2}{*}{$\begin{array}{c}\text { Initial } \\
\text { plant } \\
\text { response } \dagger\end{array}$} & \multirow[b]{2}{*}{$\underset{\text { isolates }}{\mathrm{Km}^{\mathrm{R}}}$} & \multicolumn{4}{|c|}{ Plant responses to isolates from initial hosts $\dagger$} \\
\hline & & & & Pea & $\begin{array}{l}\text { White } \\
\text { clover }\end{array}$ & $\begin{array}{l}\text { Red } \\
\text { clover }\end{array}$ & $\begin{array}{l}\text { Sub. } \\
\text { clover* }\end{array}$ \\
\hline \multirow[t]{2}{*}{ RCR5(pJB5JI) } & Pea & $\mathrm{F}^{-}$ & $5 / 5$ & $5 \mathrm{~F}^{-}$ & $4 \mathrm{~F}^{+}, 1 \mathrm{~F}^{-}$ & $4 \mathrm{~F}^{+}, 1 \mathrm{~F}^{-}$ & $5 \mathrm{~F}^{-}$ \\
\hline & $\begin{array}{l}\text { White clover } \\
\text { Red clover } \\
\text { Sub. clover }\end{array}$ & $\begin{array}{l}\mathrm{F}^{+} \\
\mathrm{F}^{+} \\
\mathrm{F}^{-}\end{array}$ & $\begin{array}{l}4 / 5 \\
5 / 5 \\
3 / 3\end{array}$ & $\begin{array}{r}4 \mathrm{~F}^{-}, \\
3 \mathrm{~N}^{-} \\
3 \mathrm{~F}^{-}\end{array}$ & $\begin{array}{l}4 \mathrm{~F}^{+} \\
4 \mathrm{~F}^{+} \\
3 \mathrm{~F}^{+}\end{array}$ & $\begin{array}{r}3 \mathrm{~F}^{+}, 1 \mathrm{~F}^{-} \\
5 \mathrm{~F}^{+} \\
3 \mathrm{~F}^{+}\end{array}$ & $\begin{array}{l}4 \mathrm{~F}^{-} \\
5 \mathrm{~F}^{-} \\
3 \mathrm{~F}^{-}\end{array}$ \\
\hline \multirow[t]{2}{*}{ RCR32(pJB5JI) } & Pea & $\mathrm{F}^{-}$ & $5 / 5$ & $3 \mathrm{~F}^{-}$ & $4 \mathrm{~F}^{+}$ & $4 \mathrm{~F}^{+}$ & $4 \mathrm{~F}^{-}$ \\
\hline & $\begin{array}{l}\text { White clover } \\
\text { Red clover } \\
\text { Sub. clover }\end{array}$ & $\begin{array}{l}\mathrm{F}^{+} \\
\mathrm{F}^{+} \\
\mathrm{F}^{-}\end{array}$ & $\begin{array}{l}2 / 5 \\
5 / 5 \\
3 / 4\end{array}$ & $\begin{array}{r}3 \mathrm{~N}^{-}, 2 \mathrm{~F}^{-} \\
1 \mathrm{~N}^{-}, 4 \mathrm{~F}^{-} \\
4 \mathrm{~F}^{-}\end{array}$ & $\begin{array}{r}5 \mathrm{~F}^{+} \\
2 \mathrm{~N}^{-}, 3 \mathrm{~F}^{+} \\
3 \mathrm{~F}^{-}, 1 \mathrm{~F}^{+}\end{array}$ & $\begin{array}{r}5 F^{+} \\
5 F^{+} \\
1 F^{-}, 3 F^{+}\end{array}$ & $1 \mathrm{~N}^{-}, \begin{array}{l}5 \mathrm{~F}^{-} \\
3 \mathrm{~F}^{-} \\
4 \mathrm{~F}^{-}\end{array}$ \\
\hline \multirow[t]{2}{*}{ RCR46(pJB5JI) } & Pea & $\mathrm{F}^{+}$ & $5 / 5$ & $5 \mathrm{~F}^{+}$ & $4 \mathrm{~F}^{-}$ & $5 \mathrm{~F}^{+}$ & $5 \mathrm{~F}^{+}$ \\
\hline & $\begin{array}{l}\text { White clover } \\
\text { Red clover } \\
\text { Sub. clover }\end{array}$ & $\begin{array}{l}\mathrm{F}^{+} \\
\mathrm{F}^{+} \\
\mathrm{F}^{+}\end{array}$ & $\begin{array}{l}5 / 5 \\
5 / 5 \\
4 / 5\end{array}$ & $\begin{array}{r}\quad 5 \mathrm{~N}^{-} \\
1 \mathrm{~N}^{-}, 3 \mathrm{~F}^{+} \\
2 \mathrm{~N}^{-}, 3 \mathrm{~F}^{+}\end{array}$ & $\begin{array}{r}1 N^{-}, 4 \mathrm{~F}^{+} \\
4 \mathrm{~F}^{+} \\
5 \mathrm{~F}^{+}\end{array}$ & $\begin{array}{l}5 \mathrm{~F}^{+} \\
4 \mathrm{~F}^{+} \\
5 \mathrm{~F}^{+}\end{array}$ & $\begin{array}{l}5 F^{+} \\
4 F^{+} \\
5 F^{+}\end{array}$ \\
\hline \multirow[t]{2}{*}{ RCR221(pJB5JI) } & Pea & $\mathrm{F}^{-}$ & $5 / 5$ & $4 \mathrm{~F}^{-}$ & $5 \mathrm{~F}^{+}$ & $5 \mathrm{~F}^{+}$ & $5 \mathrm{~F}^{+}$ \\
\hline & $\begin{array}{l}\text { White clover } \\
\text { Red clover } \\
\text { Sub. clover }\end{array}$ & $\begin{array}{l}\mathrm{F}^{+} \\
\mathrm{F}^{+} \\
\mathrm{F}^{+}\end{array}$ & $\begin{array}{l}4 / 5 \\
4 / 4 \\
4 / 5\end{array}$ & $\begin{array}{r}3 \mathrm{~N}^{-}, 2 \mathrm{~F}^{-} \\
1 \mathrm{~N}^{-}, 4 \mathrm{~F}^{-} \\
4 \mathrm{~F}^{-}\end{array}$ & $\begin{array}{l}5 \mathrm{~F}^{+} \\
5 \mathrm{~F}^{+} \\
4 \mathrm{~F}^{+}\end{array}$ & $\begin{array}{l}5 \mathrm{~F}^{+} \\
5 \mathrm{~F}^{+} \\
4 \mathrm{~F}^{+}\end{array}$ & $\begin{array}{l}2 \mathrm{~F}^{-}, 3 \mathrm{~F}^{+} \\
2 \mathrm{~F}^{-}, 3 \mathrm{~F}^{+} \\
4 \mathrm{~F}^{+}\end{array}$ \\
\hline \multirow[t]{2}{*}{ RCR226(pJB5JI) } & Pea & $\mathrm{F}^{+}$ & $5 / 5$ & $4 \mathrm{~F}^{+}$ & $2 \mathrm{~N}^{-}, 3 \mathrm{~F}^{-}$ & $2 \mathrm{~N}^{-}, 2 \mathrm{~F}^{-}$ & $3 \mathrm{~F}^{+}$ \\
\hline & $\begin{array}{l}\text { White clover } \\
\text { Red clover } \\
\text { Sub. clover }\end{array}$ & $\begin{array}{l}\mathrm{F}^{-} \\
\mathrm{F}^{-} \\
\mathrm{F}^{+}\end{array}$ & $\begin{array}{l}2 / 4 \\
2 / 3 \\
5 / 5\end{array}$ & $\begin{array}{r}2 \mathrm{~N}^{-}, 2 \mathrm{~F}^{-} \\
3 \mathrm{~F}^{+}, 1 \mathrm{~F}^{-} \\
5 \mathrm{~F}^{+}\end{array}$ & $\begin{array}{r}3 \mathrm{~F}^{-} \\
3 \mathrm{~F}^{-} \\
1 \mathrm{~N}^{-}, 4 \mathrm{~F}^{-}\end{array}$ & $\begin{array}{l}2 \mathrm{~N}^{-}, 2 \mathrm{~F}^{-} \\
1 \mathrm{~N}^{-}, 2 \mathrm{~F}^{-} \\
3 \mathrm{~N}^{-}, 2 \mathrm{~F}^{-}\end{array}$ & $\begin{array}{r}3 \mathrm{~F}^{+} \\
1 \mathrm{~F}^{+} \\
2 \mathrm{~N}^{-}, 2 \mathrm{~F}^{+}\end{array}$ \\
\hline \multirow[t]{2}{*}{ RCR227(pJB5JI) } & Pea & $\mathbf{N}^{-}$ & - & - & - & - & - \\
\hline & $\begin{array}{l}\text { White clover } \\
\text { Red clover } \\
\text { Sub. clover }\end{array}$ & $\begin{array}{l}\mathrm{F}^{-} \\
\mathrm{F}^{-} \\
\mathrm{F}^{+}\end{array}$ & $\begin{array}{l}3 / 4 \\
4 / 5 \\
3 / 4\end{array}$ & $\begin{array}{r}2 \mathrm{~N}^{-}, 2 \mathrm{~F}^{-} \\
3 \mathrm{~N}^{-}, 2 \mathrm{~F}^{-} \\
4 \mathrm{~F}^{-}\end{array}$ & $\begin{array}{l}4 \mathrm{~F}^{-} \\
5 \mathrm{~F}^{-} \\
4 \mathrm{~F}^{-}\end{array}$ & $\begin{array}{r}\quad 4 \mathrm{~N}^{-} \\
2 \mathrm{~N}^{-}, 2 \mathrm{~F}^{-} \\
3 \mathrm{~N}^{-}, 1 \mathbf{F}^{-}\end{array}$ & $\begin{array}{r}\quad 4 \mathrm{~F}^{-} \\
2 \mathrm{~F}^{-}, 3 \mathrm{~F}^{+} \\
2 \mathrm{~F}^{-}, 2 \mathrm{~F}^{+}\end{array}$ \\
\hline
\end{tabular}

* Sub., subterranean.

$\dagger \mathrm{F}^{+}, \mathrm{Fix}^{+} ; \mathrm{F}^{-}, \mathrm{Fix}^{-} ; \mathrm{N}^{-}, \mathrm{Nod}^{-}$. The plant response results show the number of plants used and the number of isolates from the initial hosts that were re-tested.

$\ddagger$ The proportion of isolates, from the initial hosts, that were still resistant to kanamycin. One nodule per plant was sampled.

\section{Inoculation tests using isolates from nodules}

In the second nodulation tests, pea and clover plants were inoculated by those transconjugants which were isolated from nodules (Table 2). All six strains isolated from white clover had changed in their ability to nodulate peas, especially isolates from strains RCR5(pJB5JI) and RCR46(pJB5JI) where all replicates failed to nodulate peas. The nodule isolates for the four other strains varied in their ability to nodulate peas. However, with the exception of one clone of RCR46(pJB5JI), these white clover isolates had not changed in their ability to nodulate white clovers (Table 2).

\section{Study of the deleted plasmids}

Agarose gel electrophoresis. Plasmid profiles of transconjugant strains isolated from nodules are shown in Fig. 1. Some profiles, notably of pea nodule isolates, are identical to those of the inoculant strains. However, plasmid rearrangements have occurred, and loss of all or part of pJB5JI is apparent in many clover nodule isolates.

$\mathrm{Re}$-isolates from clover.nodules found to have lost kanamycin resistance were investigated further. In strain RCR32(pJB5JI) derivatives, the white clover selection had resulted in the total loss of pJB5JI in all three kanamycin-sensitive isolates tested, which accounts for the Nod ${ }^{+}$ phenotype observed in the next plant inoculation tests. But derivatives of RCR226(pJB5JI) were found to have deletions in pJB5JI instead of total loss in all five of the kanamycin-sensitive isolates tested. Interestingly, in some of the RCR226(pJB5JI) derivatives, pJB5JI had small 


\begin{tabular}{|c|c|c|c|c|c|c|c|}
\hline \multirow{2}{*}{\multicolumn{2}{|c|}{$\begin{array}{c}\text { Recipient } \\
\text { strain crossed } \\
\text { with } \mathrm{T} 83 \mathrm{~K} 3\end{array}$}} & \multirow[b]{2}{*}{$\begin{array}{l}\text { T83K } 3 \\
\text { donor }\end{array}$} & \multirow[b]{2}{*}{$\begin{array}{c}\text { Trans- } \\
\text { conjugant }\end{array}$} & \multicolumn{4}{|c|}{ Isolates from first plant selection } \\
\hline & & & & Pea & $\begin{array}{l}\text { White } \\
\text { clover }\end{array}$ & $\begin{array}{l}\text { Red } \\
\text { clover }\end{array}$ & $\begin{array}{l}\text { Subterranean } \\
\text { clover }\end{array}$ \\
\hline RCR5 & $\equiv$ & $\equiv{ }_{\mathrm{EJB5J1}}$ & $\equiv$ & 三三三三 & $\begin{array}{l}\text { 三ニニニ } \\
\text { ニニニ }\end{array}$ & $\begin{array}{l}\equiv \equiv \equiv \equiv \equiv \\
\text { 三ニ二 }\end{array}$ & 三三三 \\
\hline RCR32 & $\equiv$ & $\begin{array}{l}\equiv \\
\equiv \\
\equiv \mathrm{pJSJl}\end{array}$ & $\equiv$ & 三三三三三 & 三三三三三三三 & 三三三三三三三三 & 三三三三三三 \\
\hline RCR46 & $=$ & $\equiv_{\mathrm{EJB5JI}}$ & $=$ & $\begin{array}{l}=ニ== \\
----\end{array}$ & $\begin{array}{l}==== \\
-----\end{array}$ & $\begin{array}{l}=-= \\
--\end{array}$ & $\begin{array}{l}==- \\
--\end{array}$ \\
\hline RCR221 & $\equiv$ & $\underbrace{}_{\mathrm{pJB} 5 \mathrm{Jl}}$ & $\equiv$ & $\begin{array}{l}\equiv \equiv \equiv \equiv \\
---ー\end{array}$ & $\begin{aligned} \equiv \equiv \equiv & \\
\text { 二- } & \end{aligned}$ & $\begin{array}{c}\equiv \equiv \equiv \equiv \\
-\equiv- \\
-\end{array}$ & $\begin{array}{l}\equiv \equiv \equiv \\
---E\end{array}$ \\
\hline RCR226 & $=$ & $\equiv_{{ }_{p J B 5 J I}}$ & $=$ & $\begin{array}{c}=ニ= \\
---=\end{array}$ & $\begin{array}{c}=ニ=二 \\
---\end{array}$ & $\begin{array}{l}=ニ ニ= \\
--ー-~\end{array}$ & $\begin{array}{l}==ニ \\
--=\end{array}$ \\
\hline $\mathrm{RCR} 227$ & $\equiv$ & $\equiv_{{ }_{\mathrm{pJBSII}}}$ & $\equiv$ & & 严三三三三 & $\begin{array}{l}\equiv \equiv \equiv \equiv \equiv \equiv \\
\equiv \equiv 三 三 三\end{array}$ & $\begin{array}{l}\equiv \equiv \equiv \equiv \\
\text { 三三三三 }\end{array}$ \\
\hline
\end{tabular}

Fig. 1. Plasmid profiles of transconjugants after plant selection. The profiles of all the isolates tested are shown. RCR227 transconjugants acquired pJB5JI and one of the two smallest plasmids from T83K3. Heavy bands represent two plasmids of similar size.

deletions after the first white clover plant selection and such strains could infect peas, forming nodules which were Fix ${ }^{-}$. The size of four of the deleted plasmids was about $100 \mathrm{MDa}$ (about $30 \mathrm{MDa}$ less than pJB5JI) and less than $100 \mathrm{MDa}$ for the other plasmid. However, in the isolates from subsequent white clover nodule infections, the size of the deleted pJB5JI in the five isolates tested was only about $55 \mathrm{MDa}$. These derivatives had lost the ability to nodulate peas. This might mean that the entire nodulation and $\mathrm{N}_{2}$ fixation region is functionally incompatible, and under continued selective pressure loss of all of the non-selected genes will be observed.

One of the $55 \mathrm{MDa}$ deleted plasmids was marked by introducing Tn5 into it from the suicide plasmid pJB4JI. In crosses with $R$. leguminosarum biovar viceae strain B151 the deleted plasmid was transferred at a frequency of $10^{-4}$ per recipient, showing that the tra genes on pJB5JI were still present.

Gel blots and DNA hybridization using Tn5 and nif DNA probes. An autoradiogram of a gel blot of kanamycin-sensitive derivatives of RCR226(pJB5JI) probed with Tn5 is illustrated in Fig. 2. The Tn 5 probe hybridized to the deleted pJB5JI plasmids, the intensity of hybridization to the appropriate bands being similar to that to $\mathrm{pJB} 5 \mathrm{JI}$ from T83K 3 . This suggested that the deletion involved only part of Tn5. No hybridization with these deleted plasmids by the nif probe (which contains the structural genes for nitrogenase) was obtained, although hybridization to pJB5JI in the $R$. leguminosarum biovar viceae control strain T83K 3 was always observed. The results indicate that the deletion started in Tn5, leaving part of the transposon intact, and included nod (resulting in the failure to nodulate peas) and nif genes with homology to the nif probe. 

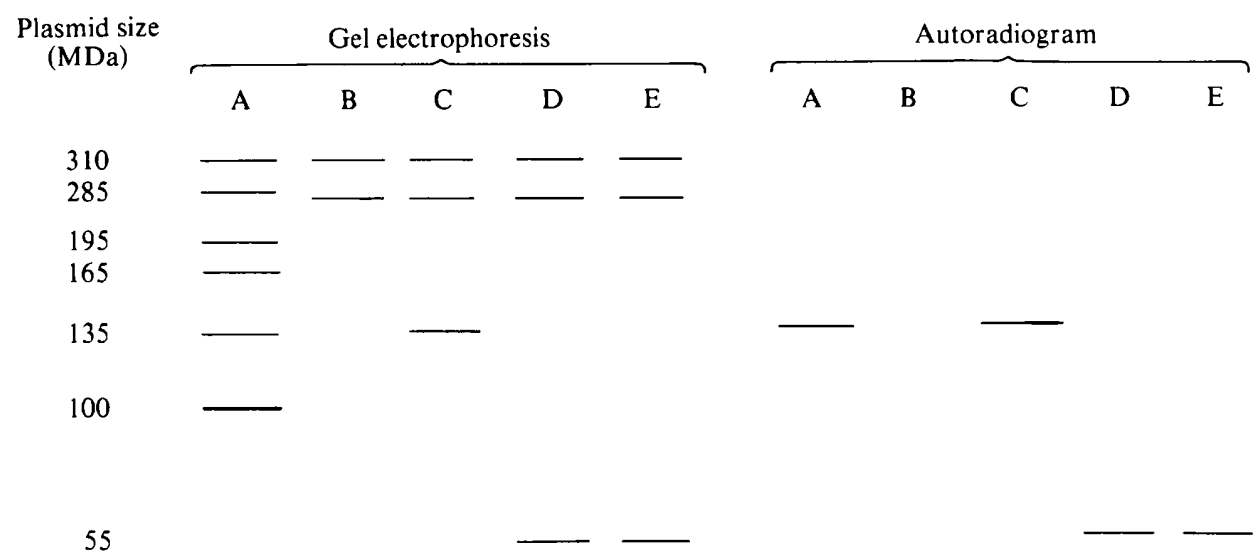

Fig. 2. Deletions in pJB5JI after plant selection. Lanes A, B and C are control strains T83K3, RCR226, RCR226(pJB5JI) respectively. Lanes D and E are derivatives of RCR226(pJB5JI), isolated from white clover nodules, with plasmid deletions. Blots of the gels were hybridized to Tn5 DNA.

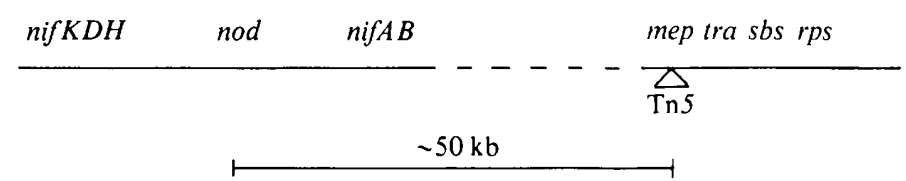

Fig. 3. Linkage of bacteriocin and tra genes in pJB5JI (C. A. Wijffelman, personal communication).

Some pea isolates from the first plant inoculation which failed to nodulate white clover were also investigated, but no physical differences were found between them and their $\mathrm{Nod}^{+}$parent strains (Fig. 1). However, RCR32(pJB5JI) derivatives that had been isolated from pea nodules and were used to re-infect peas were found, after the second isolation, to have lost or suffered deletions in two of the plasmids present in RCR32 (which were still present after the first isolation). One isolate had lost both plasmids, the other two tested had lost one and suffered a deletion in the other. The two plasmids both had homology to the nif probe and so are assumed to be Sym plasmids. The other $R$. leguminosarum biovar trifolii strains carrying pJB5JI showed no apparent change in plasmid content after the first or second isolation from pea nodules.

Bacteriocin prodution. $R$. leguminosarum biovar trifolii strain RCR32 is not sensitive to the small bacteriocin produced by $R$. leguminosarum biovar viceae strain JI6015. A pJB5JI derivative of RCR32 was examined and found to have become sensitive, demonstrating that the 'small bacteriocin sensitivity' (sbs) gene on pJB5JI is expressed in this strain.

$R$. leguminosarum biovar trifolii strain RCR226 produces a small bacteriocin to which strain RCR32(pJB5JI) is sensitive. Derivatives of RCR226 carrying pJB5JI no longer produced the small bacteriocin, demonstrating that the 'repression of small bacteriocin' (rps) gene on pJB5JI was expressed in these strains. Strains of RCR226 isolated from nodules that carried deleted derivatives of pJB5JI which had lost kanamycin resistance and nod and fix genes were still suppressed for small bacteriocin production and were still conjugative.

Plasmid pJB5JI is a derivative of plasmid pRL1JI carrying Tn5 inserted within a gene involved in medium bacteriocin production (Johnston et al., 1978). The observation that deletions of pJB5JI that removed Tn5, nod and fix genes did not affect tra or rps is consistent with the mapping of these genes in pRL1JI (see Fig. 3) by Priem \& Wijffelman (1984). RCR226(pJB5JI) strains did not become sensitive to the small bacteriocin and thus the effect of the deletion on the $s b s$ gene could not be tested in these strains. 


\section{DISCUSSION}

This study confirms previous observations that host-range genes in Rhizobium can be functionally incompatible, even though the plasmids which carry them are apparently compatible during growth of the rhizobia in laboratory media. The loss or deletion of the incorrect host nodulation plasmids after plant selection was frequently observed and successive plant selection appeared to result in more extensive deletions. This phenomenon seems to be determined by the host plants: white clover appeared to be very discriminating. Of the 27 reisolates from white clover nodules, $80 \%$ lost the ability to nodulate peas. In the less discriminating hosts, subterranean and red clover, less than $20 \%$ of nodule re-isolates had lost pea nodulation ability. About $10 \%$ of pea re-isolates could not form nodules on either white clover or red clover. In some cases the plant appeared to select those transconjugants which had undergone deletions and this selective pressure varied according to the 'stringency' of the plant.

However, the investigation shows that nodulating ability on peas varies according to the Rhizobium strain. In contrast to some previous reports, two of the $R$. leguminosarum biovar trifolii derivatives formed $\mathrm{N}_{2}$-fixing nodules on peas after transfer of pJB5JI, and this property was stably inherited.

Beringer (1982) and others have reported that some members of the Rhizobiaceae are closely related to each other. Biovars trifolii, viceae and phaseoli are now classified as members of the same species (Jordan, 1984). Indeed Prakash et al. (1981) has shown that plasmids in Agrobacterium which are involved in tumour formation contain sequences of DNA that are also found in host-range plasmids in $R$. leguminosarum biovars viceae, phaseoli and trifolii, and $R$. meliloti. It is likely that different host plant responses, which are the criterion for speciation, can be elicited by strains that only have a few genes involved in host discrimination differing betwen them. If this interpretation is correct it should be possible to isolate or produce strains which are not clearly one biovar or another.

The observation that $R$. leguminosarum biovar trifolii strain RCR32 has two plasmids which hybridize to the Klebsiella nif DNA probe is the first that we know of for this biovar. More than one copy of nif $H$ has been reported for some strains of $R$. leguminosarum biovar phaseoli (Quinto et al., 1982) and Anabaena (Rice et al., 1982; Kallas et al., 1983). Our results do not show whether other genes involved in symbiosis are found on both plasmids, although the observation that strains nodulating peas have undergone deletions in both plasmids, or deletion in one and loss of the other, suggests that at least one gene whose function is incompatible with the nodulation of peas is present on each.

\section{REFERENCES}

BERINGER, J. E. (1974). R factor transfer in Rhizobium leguminosarum. Journal of General Microbiology 84, 188-198.

BERINGER, J. E. (1982). The genetic determination of host range in the Rhizobiaceae. Israel Journal of Botany 31, 89-93.

Beringer, J. E., Hoggan, S. A. \& Johnston, A. W. B. (1978). Linkage mapping in Rhizobium leguminosarum by means of $\mathbf{R}$ plasmid-mediated recombination. Journal of General Microbiology 104, 201-207.

BEYNON, J. L., BERINGER, J. E. \& JohNSTON, A. W. B. (1980). Plasmid and host-range in Rhizobium leguminosarum and Rhizobium phaseoli. Journal of General Microbiology 120, 421-429.

Brewin, N. J., WoOd, E. A., Johnston, A. W. B., DibB, N. J. \& Hombrecher, G. (1982). Recombinant nodulation plasmids in Rhizobium leguminosarum. Journal of General Microbiology 128, 18171827.

Christensen, A. H. \& Schubert, K. R. (1983). Identification of a Rhizobium trifolii plasmid coding for nitrogen fixation and nodulation genes and its interaction with pJB5JI, a Rhizobium leguminosarum plasmid. Journal of Bacteriology 156, 592-599.

DJoRdjevic, M. A., ZuRkowski, W. \& Rolfe, B. G. (1982). Plasmids and stability of symbiotic properties of Rhizobium trifolii. Journal of Bacteriology 151, 560-568.

FAHRAEUS, G. (1957). The infection of clover root hairs by nodule bacteria studied by a simple glass slide technique. Journal of General Microbiology 16, 374381.

Higashi, S. (1967). Transfer of clover ineffectivity of Rhizobium trifolii to Rhizobium phaseoli is mediated by an episomic factor. Journal of General and Applied Microbiology 13, 391-403.

HIRSCH, P. R. (1979). Plasmid-determined bacteriocin production by Rhizobium leguminosarum. Journal of General Microbiology 113, 219-228.

Hirsch, P. R., Johnston, A. W. B., Brewin, N. J., Van Montagu, M. \& Schell, J. (1980). Physical identification of bacteriocinogenic, nodulation and other plasmids in strains of Rhizobium leguminosarum. Journal of General Microbiology 120, 403-412. 
Hombrecher, G., BREwIN, N. J. \& JOHNSTON, A. W. B. (1981). Linkage of genes for nitrogenase and nodulation ability on plasmids in Rhizobium leguminosarum and Rhizobium phaseoli. Molecular General Genetics 182, 133-136.

JOHNSTON, A. W. B. \& BERINGER, J. E. (1975). Identification of the Rhizobium strains in pea roots nodules. Journal of General Microbiology 87, 343--350. JOHNSTON, A. W. B. \& BERINGER, J. E. (1977). Chromosomal recombination between Rhizobium species. Nature, London 267, 611-613.

Johnston, A. W. B., Beynon, J. L., BuchanaNWollaston, A. V., Setchell, S. M., Hirsch, P. R. \& BERINGER, J. E. (1978). High frequency transfer of nodulating ability between strains and species of Rhizobium. Nature, London 276, 635-636.

JORDAN, D. C. (1984). Rhizobiaceae. In Bergey's Manual of Systematic Bacteriology, vol. 1, pp. 234256. Edited by N. R. Krieg. Baltimore \& London: Williams \& Wilkins.

Kallas, T., Reriere, M. C., Rippka, R. \& Tandeau DE MARSAC, N. (1983). The structural nif genes of the cyanobacteria Gloethece sp. and Calothrix sp. share homology with those of Anabaena sp. but the Gloethece genes have a different arrangement. Journal of Bacteriology 32, 511-519.
Prakash, R. K., Schilperoort, R. A. \& Nuti, M. P. (1981). Large plasmids of fast-growing Rhizobia; homology studies and location of structural nitrogen fixation (nif) genes. Journal of Bacteriology 145, I129-1136.

Priem, W. J. T. \& Wijffelman, C. A. (1984). Selection of cured strains and mutants of the Sym plasmid pRL.1Jl by small bacteriocin. In Advances in Nitrogen Fixation Research, p. 717. Edited by C. Veeger \& W. E. Newton. The Hague: Nijhhoff Junk, Pudoc.

Quinto, C., De la Vega, H., Flores, M., Fernandez, L., Ballado, T., Soberon, G. \& Palacios, R. (1982). Reiteration of nitrogen fixation genes sequences in Rhizobium phaseoli. Nature, London 299 , 724-726.

Rice, D., Mazur, B. J. \& Haselkorn, R. (1982). Isolation and physical mapping of nitrogen fixation genes from the cyanobacterium Anabaena 7120. Journal of Biological Chemistry 257, 13157-13163.

VinCENT, J. M. (1970). International Biological Programme Handbook. No. 15. A Manual for the Practical Study of Root-nodule Bacteria. Oxford: Blackwell Scientific Publications. 